\title{
Characteristics of BOARDS OF Directors \\ and Perceptions of Corporate Social Responsibiltty: \\ AN EXamination of the Fortune SuRvey
}

\author{
Joseph W. Hoft \\ Union Pacific Railroad Co. \\ St. Louis, Missouri \\ J. David Hunger \\ Charles B. Shrader \\ Iowa State University \\ Ames, Iowa
}

\section{Introduction}

Is there any relation between the composition of a corporation's board of directors and the corporation's level of social responsibility? In a recent article, Hambrick and Mason [6] propose that top management has a strong impact on organizational outcomes. Specifically, they argue in favor of an "upper echelons perspective" which states that strategic choices and organizational performance can be partially predicted by background characteristics and the composition of the top management team. This perspective is based on March and Simon's [8] view that each decision maker brings his or her own set of "givens" to an administrative situation. Thus, a person's cognitive base and values affect strategic choices and organizational performance through their impact on managerial perceptions.

O'Neill, Saunders, and McCarthy [11, p. 5] note that research offers support for the upper echelons perspective for both top management and the board of directors. It is well accepted that chief executives have a strong impact on the strategic direction of their firms [2, p. 315]. In a survey of top investment analysts and money managers, for example, almost half responded that their personal evaluation of top management is worth $60 \%$ of their total evaluation of a company [12, pp. 35-36]. Although boards of directors are only supposed to exercise a general corporate leadership role and not to involve themselves in day-to-day operations, an evolving research stream suggests that there is an indirect link between the composition and structure of the board of directors and company performance [16].

The trend to add more "outsiders" (people not employed by the corporation) to a corporation's board of directors reveals an implicit acceptance of the upper echelons perspective that boards can indirectly affect organizational performance [16]. The American Law Institute, for example, proposes that all corporations be required to have outside directors form a majority of the membership of their boards of directors. The Securities and Exchange Commission requires corporations whose stock is listed on the New York Stock Exchange to have at least two outside directors. These outside directors are expected to staff the board's audit committee. The addition of outsiders to a board is thought by many to make top management more accountable to key stakeholders in the company's 
task environment [7]. The presence of outsiders on the board has also been found to improve the organization's ability to secure scarce resources from the environment [13]. Consequently, there is increasing support to broaden the perspective of the board through "the addition of individuals with different backgrounds and experience, who would bring fresh perspectives and values to board decision-making" [3, p. 41].

A major role of the board is to provide guidance and direction relative to the demands of society placed on the firm [16]. In his call for reforming corporate governance, Nader $[10$, p. 130] states that "the display of ethical behavior at its beights reflects the guiding hand of the people at the top who set the tone and direction." Research by Zahra and Stanton [17] of 100 large United States companies reveals that a company's commitment to social responsibility (as evidenced by statements in its annual report) is related to board size as well as to outsider and minority representation on the board. Their conclusion is that larger boards that are dominated by outsiders are more conducive to corporate social responsibility than are smaller boards with less outsiders. A study by O'Neill, Saunders, and McCarthy [11] comparing the responses by board members to a social responsibility questionnaire to board member characteristics reveals that a board member's orientation toward corporate social responsibility is related positively to his/her age and educational level and negatively to his/her financial stake in the company. In agreement with the previously mentioned Zahra and Stanton study, O'Neill et al. find that outside directors have a greater orientation toward corporate social responsibility (as measured by the selfreport measure) than do inside directors. The key variable may be the insider-outsider distinction since outsiders in the $O^{\prime} N$ eill et al. study tended to have a higher educational level and owned less stock in the company than did insiders. These and other studies support the contention that the background characteristics of board members are related in some fashion to corporate social responsibility. Both the Zahra and Stanton and the O'Neill, Saunders, and McCarthy studies are flawed, however, by their use of self-report measures of corporate social responsibility. Such measures are susceptible to personal bias. O'Neill et al. admit this limitation by stating that "orientation toward corporate social responsiveness does not guarantee that the corporation will behave in a manner consistent with the orientation of the outside board members" [11, p. 21].

\section{Variables of the Study}

This study attempts to add to the knowledge regarding boards of directors and corporate social responsibility and to deal with some of the limitations of previous studies. In line with the upper echelon perspective proposed by Hambrick and Mason, the study assumes that the characteristics of a corporation's board of directors have a definite, although indirect, impact upon a company's activities and performance. The following variables describing the board of directors are correlated with a measure of corporate social responsibility: (1) percentage of insiders on the board, (2) percentage of major stockholders on the board, (3) CEO (Chief Executive Officer) or COB (Chairman of the Board) remuneration, (4) mean age of directors, (5) standard deviation of directors' ages, and (6) size of the board. 


\section{Percentage of Insiders on the Board}

As previously mentioned, the upper echelons perspective suggests that the background, values and cognitive ability of the individual board members greatly affect the agenda and strategic policies of the corporation. It is, therefore, assumed that those members on the board who are not insiders will bring different cognitive backgrounds and values with them to the board room. Therefore, a firm with fewer insiders as a percentage of the board as a whole is likely to be more responsible towards society and to direct the corporation toward socially responsible actions. This reasoning is in line with previous studies by Zahra and Stanton, and O'Neill, Saunders, and McCarthy.

\section{Percentage of Major Stockholders on the Board}

It is assumed that board members who are also major stockholders in the corporation (owning over 1000 shares) will have goals and values leaning toward the increasing of earnings of the stockholders. Therefore, they will not have corporate social responsibility as a main goal, and the board will, consequently, devote less attention to corporate social responsibility as the percentage of major owners on the board increases. In agreement with the findings of $\mathrm{O}^{\prime} \mathrm{Neill}$ et al., we assume a negative correlation between corporate responsibility and the percentage of owners on the board.

\section{CEO/COB Remuneration}

Commitment to employees is a socially responsible action because employees have a large stake in the corporation. However, we believe that major officers in the corporation can be paid too much or too little. When the remuneration of a CEO or COB exceeds a certain point, then the act of distributing the salary is socially irresponsible since the money that goes to top management could be better used in other areas. We assume that the closer the CEO's or COB's salary is to the mean CEO or COB salary, the more that corporation is likely to be viewed as being generally socially responsible.

\section{Mean Age of Directors}

In agreement with the O'Neill, Saunders, and McCarthy study, it is hypothesized that age should be related positively to social responsibility. Older board members will likely have a great deal of managerial experience, and will probably seek more information in decision making processes and tend to go beyond purely utilitarian concerns when confronting complex problems.

\section{Standard Deviation of Directors' Ages}

Beginning with the assumption that diversity in backgrounds will be reflected in a diversity of perspectives on a board of directors, it is hypothesized that there is a positive relationship between corporate social responsibility and the standard deviation of directors' ages. Differences in ages should reflect differences in experiences and should, thus, encourage more diverse perspectives on a complex situation. More diverse perspectives should create a richer discussion of problems and alternatives - one more likely to consider non-financial side effects. 


\section{Size of the Board}

In agreement with Zahra and Stanton, it is hypothesized that more socially responsible corporations have larger boards (in terms of number of members) than do less socially responsible corporations. The reasoning is similar to that regarding the standard deviation of directors' ages. The larger the board, the greater the number of perspectives on any given issue, and thus, the greater likelihood that non-financial questions will be dealt with in board discussions.

\section{Corporate Social Responsibility}

Findings from the Zahra and Stanton, and O'Neill, Saunders, and McCarthy studies are limited because of their use of self-report measures of social responsibility. This study, in contrast, uses the opinions of outside observers, which hopefully act as a more objective measure. Data on corporate social responsibility were obtained from Fortune magazine's annual survey of corporate reputations. Published in January 1989, the survey measured 305 United States corporations in 32 industries. Over 8,000 senior executives, outside directors, and financial analysts rated the ten (in some cases less than ten) largest corporations in their own industry on eight key attributes of reputation, using a scale of $\mathbf{0}$ (poor) to 10 (excellent). The attributes were: quality of management; quality of products or services; innovativeness; long-term investment value; financial soundness; ability to attract, develop, and keep talented people; community and environmental responsibility; and wise use of corporate assets.

Used previously in studies of corporate social responsibility and financial performance, the Fortune ratings correlated well with other social responsibility measures - thus, providing evidence for validity - as well as with previous Fortune ratings - thus, providing evidence of reliability [9, pp. 860-861]. As pointed out by Spencer and Taylor [14], the advantage of this survey is that all the ratings were made by outside experts about firms in their own industry which should help to ensure that respondents have some knowledge of the activities of the firm they are rating, without being overly biased. Other advantages of this survey are that it provides comparable data over an extended period and that the number of respondents is comparable or superior to those of other ratings [9].

Although Fortune's "community and environmental responsibility" rating does not incorporate all the many aspects of social responsibility as defined by Carroll [4] and others, we feel that it does capture a key segment of a corporation's overall social responsibility.

\section{Methodology of the Study}

The Fortune community and environmental responsibility rating was correlated with the six variables of the board of directors: percentage of insiders on the board, percentage of major stockholders on the board, CEO's or COB's remuneration, mean age of directors, standard deviation of director's ages, and size of the board. The information on these variables was taken from the Disclosure database. Since the Fortune survey took place from September 13, 1988 to November 1, 1988, the lists of board members elected for 
coming terms in early 1988 and late 1987 were obtained, as well as information needed for each corporation. Information on all the variables for each corporation was only available in the database for $\mathbf{2 5 5}$ of the $\mathbf{3 0 5}$ corporations listed in the Fortune survey. To check whether there was evidence that the missing corporations were not random i.e., the missing corporations might be socially irresponsible concerns, we compared the mean value of the Fortune rating for our data with the mean value of the 305 corporations in the Fortune survey. The mean score for the responsibility to the community and environment rating for our data set of 255 companies was 6.208 as compared to 6.142 for all 305 companies. A t-test revealed that there was no significant difference between the two means.

Data were collected on the six variables. The number of insiders on each board was divided by the number of members on the board to obtain the percentage of insiders on the board. The number of major stockholders on each board (those with more than 1,000 shares of ownership as listed by Disclosure) was divided in the same manner to arrive at the percentage of major stockholders on the board. The ages were collected on all the members of each board and the mean age for each board of directors was tabulated. The standard deviations of the ages of the board members were also collected and tabulated. The number of board members was used as the size of the board. The CEO's or COB's remuneration was also collected depending on which was higher (in many cases the CEO and $\mathrm{COB}$ were the same person). Since we proposed that the more socially responsible the firm, the closer the CEO/COB remuneration should be to the mean average, we subtracted the mean of the CEO's/COB's remuneration for the 255 organizations collected from each corporation's CEO or COB salary. The resulting variable was named "N." We then squared this variable and named it $\mathrm{O}$ to generate a variable manifesting the total difference from the mean salary regardless of sign.

The variables are named as follows:

$\mathrm{K}=$ Fortune's Responsibility to the Community and Environment Rating

$L=$ Percentage of Insiders on the Board

$M=$ Percentage of Major Stockholders on the Board

$\mathrm{H}=$ Mean Age of Directors

$I=$ Standard Deviation of Directors' Ages

$\mathrm{N}=\mathrm{CEO} / \mathrm{COB}$ Salary - Mean CEO/COB Salary

$\mathbf{O}=\mathrm{N}$ Squared

$\mathrm{D}=$ Size of the Board

\section{Results of the Study}

The correlation matrix resulting from the application of the Statistical Package for the Social Sciences (SPSS) on the variables $K, L, M, H, I, N, O$, and D is shown in Exhibit 1. The matrix suggests a significant positive relationship between $(\mathrm{K})$ the responsibility rating and (D) the size of the board (.1836), and a significant negative relationship with (I) the standard deviation of directors' ages (-.1794). As hypothesized, the larger the size of the board (D), the higher the responsibility of the firm (K). However, we expected 
(I) the standard deviation of directors' ages to also be positively correlated with (K) social responsibility, which was not the case. The correlations of $(K)$ the responsibility rating with $(H)$ the mean age of directors, $(\mathrm{L}$ ) percentage of insiders, $(M)$ percentage of owners (major stockholders), (N) CEO/COB salary minus the mean, and $(O)$ the $\mathrm{N}$ squared variable were not significant.

A significant positive correlation was found between (D) the size of the board and (N) CEO/COB salary minus the mean salary (.2198). Thus, firms with larger boards tend to pay higher than average salaries to their chief executives. Significant negative correlations were found between $(\mathrm{H})$ the mean age of directors and both $(\mathrm{L})$ the percentage of insiders $(-.2736)$ and $(O)$ CEO/COB salary minus the average salary squared (-.1476). The first of these indicates that the higher the mean age of the directors, the lower the number of insiders as a percentage of total board membership. Thus, boards with older members tend to have a greater percentage of outsiders than do younger aged boards. The negative correlation of $(\mathrm{H})$ the mean age of directors and $(\mathrm{O}) \mathrm{CEO} / \mathrm{COB}$ salary minus the average salary squared indicates that boards with older members tend to pay their chief executives closer to the mean average salary than do younger boards. A significant positive correlation was found between $(L)$ the percentage of insiders on the board and $(M)$ the percentage of major stockholders (.2174). This suggests that either many insiders on the boards are also major stockholders or that major stockholders on the boards tend to keep the number of outsiders on the boards to a minimum. The high positive relation (.6204) between (N) CEO/COB salary minus the mean salary and (O) N squared is basically as expected.

\section{Conclusion}

This study found a significant positive relationship between the Fortune ratings of a company's community and environmental responsibility and the size of its board of directors as well as a negative relationship between the ratings and the standard deviation of the directors' ages. In agreement with the Zahra and Stanton study, a company's reputation for corporate social responsibility is related to board size. Corporations with large boards tend to be perceived by others in their industry as more socially responsible. In contrast to both the Zahra and Stanton, and O'Neill, Saunders, and McCarthy studies, the Fortune rating was not significantly related to the percentage of insiders on the board. The failure of this study to find this relationship may be less a fault of the study and more a result of the trend toward an increasing percentage of outsiders on the boards of most large U.S. corporations [15, pp. 61-62]. The percentage of outside directors on the boards of the 255 companies in this study is $74 \%$. The insider-outsider distinction per se may no longer be relevant as a distinguishing characteristic of the boards of directors of large U.S. corporations.

Although this study failed to find a significant positive relationship between a company's social responsibility and directors' age, as was found by O'Neill et al, it did find that age homogeneity was significantly related to a firm's responsibility rating. It is possible that age heterogeneity may create conflict on the board, thus preventing the consensus needed for a board to influence the corporation's social agenda. The failure of this study to find 
any significant relationship between the responsibility rating and the percentage of major stockholders on the board as was found by O'Neill $e t a l$., is harder to explain. The percentage of board members who are major stockholders in this study is $46 \%$. Perhaps major stockholders do not focus only on economic returns as suggested by O'Neill et al., but also consider longer-term social issues as well. Major stockholders may be more concerned with the long-term success of their company and less with short-turn economic gain than are those who own less stock in the company.

As with most research efforts, some of our assumptions and decisions with regard to the inclusion of variables can be questioned. For example, we included two "age" measures - one based on the mean, and the other on the standard deviation. This is a rather rough attempt to get a sense of board heterogeneity. The standard deviation of age appears to be the better measure and should be included as part of more sophisticated composite measures of heterogeneity in future research. Additionally, there may be many other board composition variables which affect social responsibility. Studies adopting different measures such as educational level or interlocks might produce more illuminating findings. Finally, our use of the Fortune survey can be criticized because even though it is a survey of top management, it includes only one element of social responsibility, namely, community and environmental responsibility. Indeed, social responsibility is more complex than this. Future studies addressing the affect of board composition on social responsibility should use instruments which are based on more comprehensive models and which have tested reliability and validity such as the one developed by Aupperle, Carroll, and Hatfield [1].

In conclusion, this research should prove useful to top executives and board chairmen who are charged with overseeing the corporate social responsibility of their firms. The findings of this study clearly suggest that firms with larger board membership are perceived to be more socially responsible. Thus, directors and managers should consider adding members to their boards as part of developing socially relevant strategies. As firms are faced with increasingly complex environments and conflicting demands from constituent groups, the necessity for firms to be proactive with respect to social responsibilities will probably increase as well. If this pattern holds true, managers and directors can use the results of this study to structure their boards to more adequately respond to community and environmental demands. Nevertheless, more work needs to be done on this topic to resolve some of the disagreements between this research and previous studies.

\section{References}

1. Aupperle, K.E., Carroll, A.B., and Hatfield, J.D. "An Empirical Examination of the Relationship Between Corporate Social Responsibility and Profitability." Academy of Management Journal, Vol. 28 (June 1985), pp. 446-463.

2. Beatty, R.P. and Zajac, E.J. "CEO Change and Firm Performance in Large Corporations: Succession Effects and Manager Effects." Strategic Management Journal, Vol. 7 (JulyAugust 1987), pp. 305-317. 
3. Blumberg, P.I. "Who Belongs on Corporate Boards?" Business and Society Review, (Spring 1983), pp. 40-47.

4. Carroll, A.B. "A Three-Dimensional Conceptual Model of Corporate Performance." Academy of Management Review, Vol. 4 (October 1979), pp. 497-505.

5. Davenport, D. "America's Most Admired Corporations." Fortune, (January 30, 1989), pp. 68-94.

6. Hambrick, D.C. and Mason, P.A. "Upper Echelons: The Organization as a Reflection of Its Top Managers." Academy of Management Review, Vol. 9 (April 1984), pp. 193-206.

7. Kesner, I.F. and Johnson, R.B. "Board Room Crisis: Fiction or Fact." Academy of Management Executive, Vol. 4 (February 1990), pp. 23-35.

8. March, J.G. and Simon, H.A. Organizations. New York: Wiley and Sons (1958).

9. McGuire, J.P., Sundgren, A., and Schneeweis, T. "Corporate Social Responsibility and Firm Financial Performance." Academy of Management Journal, Vol. 31 (December 1988), pp. 854-872.

10. Nader, R. "Reforming Corporate Governance." Califormia Management Review, (Summer 1982), pp. 126-132.

11. O'Neill, H.M., Saunders, C., and McCarthy, A. "The Background Characteristics of Board Members and Their Orientation Toward Corporate Social Responsiveness: An Investigation From the Upper Echelons Perspective." Unpublished Working Paper (1988).

12. Pincus, T.H. “A Crisis Parachute: Helping Stock Prices Have a Soft Landing." Journal of Business Strategy, Vol. 6 (Spring 1986), pp. 32-38.

13. Shrader, C.B., Hoffman, A.N., and Stearns, T.M. "Agency Directors and Network Centrality: An Examination of Resource Dependencies." Journal of Managerial Issues, Vol. 3 (Spring 1991), pp. 46-61.

14. Spencer, B.A. and Taylor, G.S. "A Within and Between Analysis of the Relationship Between Corporate Social Responsibility and Financial Performance." Akron Business and Economic Review, (Fall 1987), pp. 7-18.

15. Wheelen, T.L. and J.D. Hunger. Strategic Management and Business Policy, 3rd edition (1989). Reading, Massachusetts: Addison-Wesley Publishing Company.

16. Zahra, S.A. and J.A. Pearce II. "Boards of Directors and Corporate Financial Performance: A Review and Integrative Model." Journal of Management, Vol. 15 (June 1989), pp. 291334. 
17. Zahra, S.A. and W.W. Stanton. "The Implications of Board of Directors' Composition for Corporate Strategy and Performance." International Journal of Management, Vol. 5 (June 1988), pp. 229-236.

\section{Exhibit 1}

\begin{tabular}{|c|c|c|c|c|}
\hline \multirow[b]{2}{*}{ Correlations } & \multicolumn{4}{|c|}{ Correlation Matrix } \\
\hline & $\frac{\mathrm{K}}{\text { (Rating) }}$ & $\begin{array}{c}\text { D } \\
\text { (Size) }\end{array}$ & $\begin{array}{c}\mathbf{H} \\
\text { (Age) }\end{array}$ & $\begin{array}{c}\text { I } \\
\text { (S.D. of Age) }\end{array}$ \\
\hline$\overline{\mathrm{K} \text { (Rating) }}$ & 1.0000 & $.1836^{*}$ & -.0508 & $-.1794^{*}$ \\
\hline D (Size) & $.1836^{*}$ & 1.0000 & .1218 & -.0628 \\
\hline H (Age) & -.0508 & .1218 & 1.0000 & -.0943 \\
\hline I (S.D. of Age) & $-.1794^{*}$ & -.0628 & -.0943 & 1.0000 \\
\hline L (\% Insiders) & .1342 & -.0446 & $-.2736^{* *}$ & .1385 \\
\hline M (\% Owners) & .1006 & -.0638 & -.0221 & .1089 \\
\hline $\mathbf{N}(\mathbf{\$}-$ Mean $)$ & .1260 & $.2198^{* *}$ & -.0045 & -.0354 \\
\hline $\mathrm{O}(\$ \text {-Mean })^{2}$ & -.1042 & -.0459 & $-.1476^{*}$ & .0731 \\
\hline Correlations & $\begin{array}{c}\mathrm{L} \\
(\% \text { Insiders })\end{array}$ & $\begin{array}{c}M \\
(\% \text { Owners })\end{array}$ & $\begin{array}{c}\mathbf{N} \\
(\$-M e a n) \\
\end{array}$ & $\begin{array}{c}0 \\
(\$-M e a n)^{2} \\
\end{array}$ \\
\hline $\mathrm{K}$ (Rating) & .1342 & .1006 & .1260 & -.1042 \\
\hline D (Size) & -.0446 & -.0638 & $.2198 * *$ & -.0459 \\
\hline H (Age) & $.2736^{* *}$ & -.0221 & -.0045 & $-.1476^{*}$ \\
\hline I (S.D. of Age) & .1385 & .1089 & -.0354 & .0731 \\
\hline L (\% Insiders) & 1.0000 & $.2174 * *$ & .0141 & .1009 \\
\hline M (\% Owners) & $.2174^{* *}$ & 1.0000 & .0854 & -.0193 \\
\hline $\mathbf{N}$ (\$-Mean) & .0141 & .0854 & 1.0000 & $.6204^{* *}$ \\
\hline$O(\$ \text {-Mean })^{2}$ & .1009 & -.0193 & $.6204^{* *}$ & 1.0000 \\
\hline
\end{tabular}

N of Cases: 255

1-Tailed Significant $\quad{ }^{*} p$ less than $.01 \quad{ }^{* *}$ p less than .001 